\title{
Mycosarcoma Maydis (Ustilago Maydis) - Benefits and Harmful Effects of the Phytopathogenic Fungus for Humans
}

\author{
Agata Wołczańska ${ }^{1 *}$ and Marta Palusińska Szysz ${ }^{2}$ \\ ${ }^{1}$ Department of Botany and Mycology, Maria Curie-Skłodowska University, Poland \\ ${ }^{2}$ Department of Genetics and Microbiology, Maria Curie-Skłodowska University, Poland
}

Received: April 14, 2018; Published: April 26, 2018

*Corresponding author: Agata Wołczańska, Faculty of Biology and Biotechnology, Institute of Biology and Biotechnology, Department of Botany and Mycology, Maria Curie-Skłodowska University, Akademicka 19 St., 20-033 Lublin, Poland

\section{Abstract}

The paper presents a phytopathogenic fungus Mycosarcoma maydis, which causes big losses in maize crops. Additionally, this maize smut exerts an impact on human health. It may be a cause of respiratory tract diseases (e.g. allergy, asthma) and other health problems called basidiomycoses. Its positive influence on humans is related to the content of bioactive compounds and minerals as well as its unusual flavour. This species may also be used for preparation of cholera vaccine and for elucidation of the cause of many human diseases.

\section{Introduction}

Mycosarcoma maydis Bref. (=Ustilago maydis (DC.) Corda) belongs to the group of microscopic phytopathogenic fungi and is a cause of maize crop losses. Its hosts are Zea mays L. and Zeamexicana (Schrad.) Kuntze. The fungus infects all parts of plants (usually the lower parts of internodes on stems, leaves, and inflorescences) and forms hypertrophied sori (galls, tumors) filled with ustilospores (teliospores, chlamydospores) [1-4]. The species is dimorphic and its life cycle consists of two stages: non-pathogenic (yeast stage) and pathogenic $[1,2,5]$. After meiosis, the diploid ustilospores grow and form a haploid promycelium, which produces haploid sporidia (basidiospores). They cannot infect plants but form a dikaryotic mycelium after fusion of two genetically compatible sporidia. Binucleate hyphae are biotrophic and need host plants, especially young meristematic tissue, for further development. The infection is always local, and hyphae penetrate plants intra- and intercellularly. The dikaryotic phase is the longest in the life cycle of smut fungi and results in fusion of nuclei and production of ustilospores $[1,2,5,6]$.

The Western Hemisphere is the origin of this species. It was first described as Lycoperdon zeae Beckm in 1768. Other synonyms of the corn smut are Uredo maydis DC, Ustilago maydis (DC.) Corda, Uredo segetum [var.] mays-zeae DC, Ustilagozeae-maydis G Winter, Ustilago mays-zeae (DC.) Magnus, Uredo zeaeSchwein., Caeomazeae Link, Ustilagozeae (Link) Unger, Ustilagoeuchlaenae Archang., and Pseudo zymaprolifica Bandoni [4,5].

\section{Impact of m. Maydis on Humans}

Phytopathogenic fungi are usually not harmful to people, although there are some exceptions, e.g. Clavicepspurpurea (Fr.) Tul. infecting inter alia cereals. Several other species (e.g. Ustilagotritici (Pers.) Rostr, Uromyces sp.) may contribute to the development or intensity of asthma and allergies. Ustilago esculenta Henn. has been noted as a cause of hypersensitivity pneumonitis [7-9]. Generally, there are insufficient data on the harmful effect of $\mathrm{M}$. maydis on human health (Table 1). The oldest information dates back to the early 20th century. At that time, there were reports of dermatomycoses, acropathy, and brain lesions, i.e. leptomeningitis and ependymitis $[10,11]$. Diseases caused by smut fungi were referred to as "ustialginomycosis" [12]. Currently, the broader term "basidiomycosis" is used for diseases caused by basidiomycetes, which include smut fungi [13].

Recently published cases of human M. maydis infection were diagnosed in immunocompromised patients, who are at risk of fungal infection [14-16]. Most of the data originate from the USA, but there are also reports of cases of the disease in Asia and Europe (Table 1). Mycotoxicoses diagnosed in Croatian children during World War II developed after consumption of maize flour contaminated with M. maydis spores. Very severe symptoms were observed, i.e. acropathy, hand and sole pruritus, oedema, erythema, and skin desquamation. No similar phenomena have been reported since that time [17]. The flour may have been additionally 
contaminated with other fungal mycotoxins, as M. maydis spores are commonly consumed in Mexico and do not cause disease symptoms. In turn, as reported by Abbas et al. corn smut galls are very often infected by mycotoxigenic fungi (Aspergillus spp., Fusarium spp.) and contaminated with mycotoxins [18].

Table 1: Examples of the M. maydis impact on human health.

\begin{tabular}{|c|c|c|c|}
\hline Disease & Patients & Country & Source of data \\
\hline $\begin{array}{c}\text { Respiratory allergy, } \\
\text { asthma }\end{array}$ & 48-year-oldman & USA & {$[21]$} \\
\hline $\begin{array}{c}\text { Dermatomycosis, skin } \\
\text { lesions }\end{array}$ & $\begin{array}{c}\text { 31-year-old } \\
\text { farmer }\end{array}$ & Hungary & {$[10]$} \\
\hline Mycotoxicoses & $\begin{array}{c}\text { Children(during } \\
\text { World War II) }\end{array}$ & Croatia & {$[17]$} \\
\hline $\begin{array}{c}\text { Leptomeningitis and } \\
\text { ependymitis }\end{array}$ & 55 -year-old man & USA & {$[11]$} \\
\hline $\begin{array}{c}\text { Central venous } \\
\text { catheter infection }\end{array}$ & 45 -year-old man & USA & {$[15]$} \\
\hline $\begin{array}{c}\text { Dermatosis: annular } \\
\text { erythematous plaques } \\
\text { on chest wall, knee, } \\
\text { and over nasal vale }\end{array}$ & $\begin{array}{c}\text { 23-year-old } \\
\text { woman }\end{array}$ & Singapore & {$[16]$} \\
\hline Fungal peritonitis & 3-year-old male & USA & {$[14]$} \\
\hline
\end{tabular}

M. maydis spores are present in large amounts in the air during the fall. These spores can cause immediate skin sensitivity in patients with bronchial asthma and late phase skin sensitivity in patients with rhinitis [19-21]. A positive side of M. maydis is its nutritional value. The fungus is sometimes called "huitlacoche", "maizteca mushroom", "Mexican truffle", "Azteca Caviar" due to its unique, unusual flavour. Young smut galls are edible and treated as delicacy in Latin American countries and Turkey [5,22]. Moreover, given its high content of bioactive compounds, the species exhibits health-enhancing properties [22,23]. It contains large amounts of protein (12\% dry base) and low-fat content (up to $6.5 \%$ dry base); hence, it can be used in vegetarian and low-calorie diets [23]. The species has a beneficial effect on the digestive system due to the high level of cellulose (11\% dry base). It exhibits anticarcinogenic and antioxidant activity due to the content of ß-glucans and phenolic compounds, and the level of ergosterol with anti-inflammatory properties and a cardiovascular protector effect is comparable to that in Ganoderma lucidum (Curtis) P. Karst Commercialized in China as a dietary supplement.

Additionally, it contains large amounts of important minerals: magnesium, phosphorus, calcium, and sodium [23]. The number of bioactive compounds in M. maydis depends on the variety of maize and the time of harvesting galls; it changes (decreases) during thermal processing [22]. In Mexico, M. maydis represents a group of medicinal mushrooms and is used for treating numerous illnesses. Guzman reports 9 different types of health problems that can be treated with this species. Additionally, ustilospores mixed with oil are used as medicament to soften and soothe baby's skin after irritation [24]. Particularly noteworthy are the efforts focused on the application of M. maydis for production of a cholera vaccine. M. maydis is one of the few species with a completely identified genome. It has been genetically engineered with the CBT gene (subunit of the cholera toxin) and used for production and delivery of safe oral vaccines [25]. This species is also widely used as a model organism for investigation of interactions between a pathogen and its host in plant pathology sciences and can also be helpful in elucidation of many human diseases. As shown by Münsterkötter and Steinberg, M. maydis and humans share 777 proteins. 42 proteins of M. maydis are related to serious human diseases including cancer (8 proteins), cardiovascular disorders (7 proteins), and defects in metabolism (11proteins) [26].

\section{References}

1. Kochman J Majewski T (1973) Głowniowe (Ustilaginales). Grzyby (Mycota). VWarszawa: Państwowe Wydawnictwo Naukowe.

2. Banuett F (1992) Ustilago maydis, the delightful blight. Trends Genet 8(5): 174-180.

3. Vánky K (2012) Smut fungi of the world. St Paul: APS Press, USA 49(2-3): 163-175.

4. McTaggart AR, Shivas RG, Boekhout T, Oberwinkler F, Vánky K, et al. (2016) Mycosarcoma (Ustilaginaceae), a resurrected generic name for corn smut (Ustilago maydis) and its close relatives with hypertrophied, tubular sori. IMA Fungus 7(2): 309-315.

5. Valverde ME, López O, Pataky JK, GuevaraLara F (1995) Huitlacoche (Ustilago maydis) as a food source -biology, composition, and production. Crit Rev Food Sci Nutr 35(3): 191-229.

6. Kirk PM, Cannon PF, Minter DW, Stalpers JA (2008) Ainsworth \& Bisby's Dictionary of the Fungi. 10th Edition. Wallingford: CABI, UK.

7. Harmann T, Rolke Y, Giesbert S, Tudzynski P (2009) Ergot: from witchcraft to biotechnology. Mol Plant Pathol 10(4): 563-577.

8. Singh AB, Kumar P (2002) Common environmental allergens causing respiratory allergy in India. Indian J Pediatr 69: 245-250.

9. Yoshida K, Suga M, Yamasaki H, Nakamura K, Sato T, et al. (1996) Hypersensitivity pneumonitis induced by a smut fungus Ustilago esculenta. Thorax 51(6): 650-651.

10. Preininger T (1937-1938) DurchMaisbrand (Ustilago maydis) bedingte Dermatomykose. Arch DermatSyph 176: 109-113.

11. Moore M, Russell WO, Sachs E (1946) Chronic leptomeningitis and ependymitis caused by Ustilago, probably U. zeae (corn smut). Ustilagomycosis, the second reported instance of human infection. Am J Pathol 22(4): 761-777.

12. Mayerhofer E (1930) ÜberFälle von kindlicher "Akrodynie" (Akropathie) und ihreätiologische Beziehungzu Ustilagomai dissowieüberihre Stellungzur Feerschen Neurose. Z Kinder-Heilk 49(5): 579-588.

13. McCall MJ, Baddley JW (2010) Epidemiology of emerging fungi and fungi-like organisms. Curr Fungal Infect Rep 4: 203-209.

14. McNeil JCH, Palazzi DL (2012) Ustilago as a cause of fungal peritonitis: case report and review of the literature. J Pediatric Infect Dis Soc 1(4): 337-339.

15. Patel R, Roberts GD, Kelly DG, Walker RC (1995) Central venous catheter infection due to Ustilago species. Clin Infect Dis 21(4): 1043-1044.

16. Teo LH, Tay YK (2006) Ustilago species infection in humans. Br J Dermatol 155(5): 1096-1097.

17. Peraica M, Richter D, Rašić D (2014) Mycotoxicoses in children. ArhHig Rada Toksikol 65(4): 347-363.

18. Abbas HK, Shier WT, Plasencia J, Weaver MA, Bellaloui N, et al. (2017) Mycotoxin contamination in corn smut (Ustilago maydis) galls in the field and in the commercial food products. Food Control 71: 57-63. 
19. Crotzer V, Levetin E (1996) The aerobiological significance of smut spores in Tulsa, Oklahoma. Aerobiologia 12(1): 177-184.

20. Santilli J Jr, Rockwell WJ, Collins RP (1985) The significance of the spores of the Basidiomycetes (mushrooms and their allies) in bronchial asthma and allergic rhinitis. Ann Allergy 55(3): 469-471.

21. Wittich FW, Stakman EC (1937) Case of respiratory allergy due to inhalation of grain smuts. Journal of Allergy and Clinical Immunology 8(2): 189-193.

22. Aydoğdu M, Gölükçü M (2017) Nutritional value of huitlacoche, maize mushroom caused by Ustilago maydis. Food Sci Technol Campinas 37(4): 531-535.

23. ValdezMorales M, Carlos LC, Valverde MA, RamírezChávez E, ParedesLópez 0 (2016) Phenolic compounds, antioxidant activity and lipid profile of huitlacoche mushroom (Ustilago maydis) produced in several maize genotypes at different stages of development. Plant Foods Hum Nutr 71(4): 436-443.

24. Guzmán G (2008) Diversity and use of traditional Mexican medicinal fungi. A review. Int J Med Mushrooms 10(3): 209-217.

25. JuárezMontiel $M$, RomeroMaldonado A, MonreaEscalante E, BecerraFlora A, Korban SS, et al. (2015) The corn smut ('huitlacoche') as a new platform for oral vaccines. PLoS ONE 10(7): e0133535.

26. Münsterkötter M, Steinberg G (2007) The fungus Ustilago maydis and humans share disease-related proteins that are not found in Saccharomyces cerevisiae. BMC Genomics 8: 473.

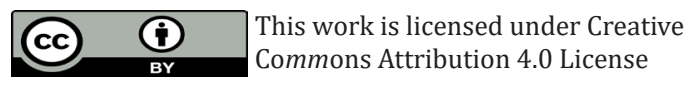

Submission Link: https://biomedres.us/submit-manuscript.php

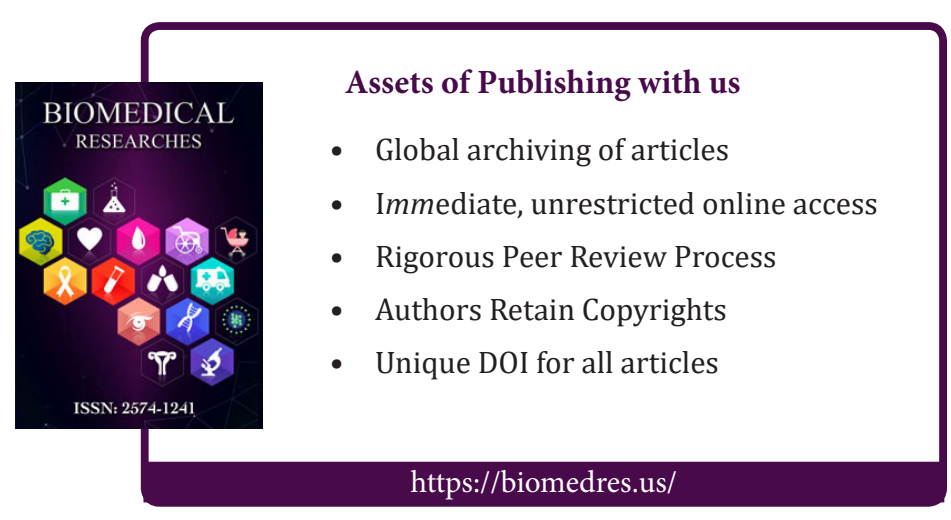

